\title{
TEFL University Instructors' Emotional Attitudes towards Their Students, Colleagues and Workplace
}

\author{
Mahsa Hariri \\ University of Applied Sciences and Technology - Bojnourd II Institute, Iran \\ E-mail: mahsa.hariri@yahoo.com
}

Received: 27-11-2013

Accepted: 08-01-2014

Published: 01-05-2014

doi:10.7575/aiac.ijalel.v.3n.3p.33

URL: http://dx.doi.org/10.7575/aiac.ijalel.v.3n.3p.33

\begin{abstract}
The purpose of this study is to search TEFL university instructors' emotional attitudes towards their students, colleagues and workplace. To accomplish this aim, a group of 30 Iranian university instructors majoring in one of the four disciplines of English language were participated. The instrument used in this study, was mainly based on a questionnaire designed by Karami and Barekat (2014) in order to ask attitudes of the participants. This questionnaire consists of 56 items under 10 categories: satisfaction, dissatisfaction, interaction with colleagues, anger towards the institutional context, anger towards students, being close to students, emotions and staff, creating rapport, collaboration and general feeling towards your career. In order to analyze the data, the descriptive statistics of each category is calculated. The analysis of data from questionnaire revealed teachers' most significant emotions in each of the 10 categories, which were mostly positive when it came to their students, and more negative in regard of their colleagues and institutional contexts. Based on the obtained results, one can draw the conclusion that EFL teachers need to talk collaboratively about their experiences and emotions.
\end{abstract}

Keywords: TEFL university instructors, emotions, operationalizing, EFL context, attitude

\section{Introduction}

Nowadays, as English is accepted as an international and standard language, special considerations are dedicated to its teaching and learning and respectively to its teachers and learners. Many studies has been investigated the teachers' cognitive and pedagogical concerns (e. g. Staub \& Stern, 2002), but as Cowie (2010) mentioned, the teachers' relationships are not limited to these aspects and emphasized on their emotional aspect that involved their relations with their students, colleagues and workplace. Koestler (1967) defined emotions as "mental states accompanied by intense feeling and (which involved) bodily changes of a widespread character" (p. 226). Hargreaves (1998) called emotion as the heart of teaching and it is charged with positive emotions. He continued that the etymology of word "emotion" belongs to emovere: to move out, or stir up. This definition points out to the fact that when people are emotional, they are moved out by their feelings. Emotional aspect of a teacher can affect his/her professional development.

Many teachers believed that they must hide their emotions from their students, but most of the time their students recognize changes in their teachers' emotions. According to Smith (1996), teachers always are in a struggle between their need to connect with other people as their colleagues, students, etc. and the need to maintain their individuality, in fact the teacher is "coherent, bounded, individualized, intentional, the locus of thought, action, and belief, the origin of its own actions, the beneficiary of a unique biography" (Rose, 1998, p. 3).

Zambylas (2005) indicated that nowadays the importance of emotions are more salient and they are considered as social, political, and cultural phenomena that its investigation is beneficial for students' learning, the climate of institutes and overall quality of education too.

As Zambylas (2005) mentioned, in spite of lots of attention on the importance of teacher's emotions, there is less investigation to this aspect of their characteristics. In fact, many studies conducted to investigate the learners' emotions, personality types and styles, and individual characteristics but there are just few studies in the realm of teachers' emotional attitudes mainly towards their students, colleagues and workplace that no one covers university instructors and the context of Iran.

\subsection{Review of Related Literature}

In this part, some of studies have been carried out to incorporate the teachers' emotions towards their students, collogues, and place work are mentioned:

Cowie (2003), interviewed nine experienced Japanese teachers who were all EFL ones. The results showed that the teachers expressed warm relationship with their students and in contrast, their relationship with their colleagues was angry and frustrating. At the end, he suggested "the theoretical frameworks of 'emotional labor' and 'feeling rules' (after Hochschild, 1983 and 1990)" (Cowie, 2003, p. 256) as a good source for teachers to follow their emotional issues collaboratively to reach to a warm relation with their students. 
Koçoğlu (2011) investigated the relationship between 90 Turkish EFL teachers' emotion and their efficacy. The results showed more efficacies of the teachers in managing the class and their progress in stress tolerance and assertiveness competencies. On the other hand, there were a positive relationship between the teachers' efficacy and their emotional intelligence (EQ).

Ghanizadeh and Moafian (2010) attempted to study the relationship between 89 Iranian EFL teachers' emotional intelligence and their success. In order to collect data, they Bar-On's 'EQ test' and a questionnaire entitled 'Characteristics of successful EFL teachers' to evaluate their performance. The results indicated that there is a significant positive relationship between teachers' success and EQ. also, significant correlations were found between teachers' EQ, their teaching experience, and their age.

Rastegar and Memarpour (2009) in a study searched the relation between emotional intelligence of Iranian teachers and their efficacy. To collect data, they used Emotional Intelligence Scale (EIS) (Schutte et al., 1998) and Teacher Sense of Efficacy Scale (TSES) (Tschannen-Moran and Woolfolk Hoy, 2001). At the end, they concluded that there is a positive relation between them. Although, they investigated the effect of genders, ages and teaching experiences on teachers' emotional intelligence and self-efficacy that found no statistically significant relations.

Nikoopour, et al. (2012) conducted a research on the relationship between emotional intelligence and self-efficacy of 336 Iranian EFL teachers. They used "Trait Emotional Intelligence Questionnaire-Short Form (TEIQue-SF)" (Petrides and Furnham, 2006) and "Teacher Sense of Efficacy Scale (TSES)" (Tschannen-Moran \& Woolfolk Hoy, 2001). They reached to the positive findings.

Prosen, Smrtnik Vitulic, and Poljsak Skraban (2011), investigated 108 German teachers' emotional expression in interaction with students of different ages. They found that teachers showed many pleasant and unpleasant emotions that the most frequent emotion was anger and then joy.

\section{Methodology}

\section{1 Participants}

The participants of this study composed of 30 university English instructors that their degrees were M. A. or PhD majoring in one of the four disciplines of English language: English teaching, translation, linguistics, or English literature. The participants composed of 13 male and 17 female instructors and their age ranges were 25-62 years old. They were teaching different English courses like general English courses for different fields of studies, or specific English courses for university students of translation, English literature, and English teaching. They were instructors of five universities in Bojnourd: Hakiman, Payem-e-noor, Kosar, and two Elmi Karbordi universities.

\subsection{Instrument}

In order to collect data, an attitude questionnaire designed and tested by Karami and Barekat (2014) was used. This questionnaire consists of 56 items under 10 categories: satisfaction (6 items), dissatisfaction (6 items), interaction with colleagues (4 items), anger towards the institutional context ( 2 items), anger towards students ( 2 items), being close to students (13 items), emotions and staff ( 2 items), creating rapport (5 items), collaboration ( 7 items) and general feeling towards your career (9 items). It must be mentioned that the reliability of all of the categories of this questionnaire was above $\alpha=0.7$ as they were measured by Karami and Barekat (2013) after implementing the pilot study and calculating through Cronbach's Alpha. The questions were organized in the form of a closed 5-point Likert scale questionnaire: Strongly Agree (1), Agree (2), Somewhat Agree/ Disagree (3), Disagree (4), Strongly Disagree (5).

\section{Results}

In this section, each category of the questionnaire analyzed through finding frequencies and percentages. For the first category which evaluates the "satisfaction" of the instructors, the data of its six items are presented in the following table:

Table 1. Item frequency and percentages of satisfaction category

\begin{tabular}{|c|c|c|c|c|c|c|c|c|c|c|}
\hline \multirow{3}{*}{ Items } & \multicolumn{10}{|c|}{ Instructors' Responses } \\
\hline & \multicolumn{2}{|c|}{$\begin{array}{c}1 \\
\text { Strongly Agree }\end{array}$} & \multicolumn{2}{|c|}{$\begin{array}{c}2 \\
\text { Agree }\end{array}$} & \multicolumn{2}{|c|}{$\begin{array}{c}3 \\
\begin{array}{c}\text { Somewhat Agree/ } \\
\text { Disagree }\end{array} \\
\end{array}$} & \multicolumn{2}{|c|}{$\begin{array}{c}4 \\
\text { Disagree }\end{array}$} & \multicolumn{2}{|c|}{$\begin{array}{c}5 \\
\text { Strongly Disagree }\end{array}$} \\
\hline & $\mathbf{F}$ & $\%$ & $\mathbf{F}$ & $\%$ & $\mathbf{F}$ & $\%$ & $\mathbf{F}$ & $\%$ & $\mathbf{F}$ & $\%$ \\
\hline 1 & 17 & 56.7 & 8 & 26.7 & 3 & 10 & 2 & 6.7 & 0 & 0 \\
\hline 2 & 3 & 10 & 7 & 23.3 & 8 & 26.7 & 8 & 26.7 & 4 & 13.3 \\
\hline 3 & 5 & 16.7 & 8 & 26.7 & 16 & 53.3 & 1 & 3.3 & 0 & 0 \\
\hline 4 & 11 & 36.7 & 6 & 20 & 7 & 23.3 & 5 & 16.7 & 1 & 3.3 \\
\hline 5 & 5 & 16.7 & 13 & 43.3 & 8 & 26.7 & 3 & 10 & 1 & 3.3 \\
\hline 6 & 17 & 56.7 & 11 & 36.7 & 2 & 6.7 & 0 & 0 & 0 & 0 \\
\hline
\end{tabular}

As Table 1 shows, in the first question, no instructors was strongly disagree with being appreciated as a good teacher and about all of them were agree or strongly agree and felt satisfied whenever they hear others appreciating them as a 
good teacher. In the second question, $66.7 \%$ of them were not agree or strongly agree that financial aspects are one of the sources of teachers' satisfaction. In the third, fourth, and fifth questions, about all of them expressed that the interaction between teachers and students is one of the reasons of their satisfaction and the fact that teachers loved their job and their satisfaction from seen of their students. In the sixth question, no instructor was disagree with his/her students' improvement.

The data given from the second category, dissatisfaction, is shown in the next table, Table 2:

Table 2. Item frequency and percentages of dissatisfaction category

\begin{tabular}{|c|c|c|c|c|c|c|c|c|c|c|}
\hline & \multicolumn{10}{|c|}{ Instructors' Responses } \\
\hline \multirow{3}{*}{ Items } & \multirow{2}{*}{\multicolumn{2}{|c|}{$\begin{array}{c}1 \\
\text { Strongly Agree }\end{array}$}} & \multirow{2}{*}{\multicolumn{2}{|c|}{$\begin{array}{c}2 \\
\text { Agree }\end{array}$}} & \multirow{2}{*}{\multicolumn{2}{|c|}{$\begin{array}{c}3 \\
\text { Somewhat Agree/ } \\
\text { Disagree }\end{array}$}} & \multirow{2}{*}{\multicolumn{2}{|c|}{$\begin{array}{c}4 \\
\text { Disagree }\end{array}$}} & \multirow{2}{*}{\multicolumn{2}{|c|}{$\begin{array}{c}5 \\
\text { Strongly Disagree }\end{array}$}} \\
\hline & & & & & & & & & & \\
\hline & $\mathbf{F}$ & $\%$ & $\mathbf{F}$ & $\%$ & $\mathbf{F}$ & $\%$ & $\mathbf{F}$ & $\%$ & $\mathbf{F}$ & $\%$ \\
\hline 7 & 15 & 50 & 13 & 43.3 & 2 & 6.7 & 0 & 0 & 0 & 0 \\
\hline 8 & 14 & 46.7 & 13 & 43.3 & 3 & 10 & 0 & 0 & 0 & 0 \\
\hline 9 & 8 & 26.7 & 10 & 33.3 & 7 & 23.3 & 3 & 10 & 2 & 6.7 \\
\hline 10 & 6 & 20 & 7 & 23.3 & 7 & 23.3 & 6 & 20 & 4 & 13.3 \\
\hline 11 & 2 & 6.7 & 5 & 16.7 & 13 & 43.3 & 6 & 20 & 4 & 13.3 \\
\hline 12 & 2 & 6.7 & 13 & 43.3 & 11 & 36.7 & 4 & 13.3 & 0 & 0 \\
\hline
\end{tabular}

The answers to the seventh and eighth questions show that all of the instructors were dissatisfied whenever they cannot do their best or when the students are not cooperating. According to the answers to the other four questions in this category, most of them are dissatisfied when they are constantly checked through observations, cameras, etc., or when they have to censor themselves mainly when the classes are heterogeneous and the traditional beliefs of students. Four questions of the third category that is about the interaction with colleagues are investigated in the Table 3 below:

Table 3. Item frequency and percentages of interaction with colleagues category

\section{Instructors' Responses}

\begin{tabular}{|c|c|c|c|c|c|c|c|c|c|c|}
\hline \multirow[t]{2}{*}{ Items } & \multicolumn{2}{|c|}{$\begin{array}{c}1 \\
\text { Strongly Agree }\end{array}$} & \multicolumn{2}{|c|}{$\begin{array}{c}2 \\
\text { Agree }\end{array}$} & \multicolumn{2}{|c|}{$\begin{array}{c}3 \\
\text { Somewhat Agree/ } \\
\text { Disagree }\end{array}$} & \multicolumn{2}{|c|}{$\begin{array}{c}4 \\
\text { Disagree }\end{array}$} & \multicolumn{2}{|c|}{$\begin{array}{c}5 \\
\text { Strongly Disagree }\end{array}$} \\
\hline & $\mathbf{F}$ & $\%$ & $\mathbf{F}$ & $\%$ & $\mathbf{F}$ & $\%$ & $\mathbf{F}$ & $\%$ & $\mathbf{F}$ & $\%$ \\
\hline 13 & 3 & 10 & 15 & 50 & 10 & 33.3 & 2 & 6.7 & 0 & 0 \\
\hline 14 & 3 & 10 & 12 & 40 & 9 & 30 & 4 & 13.3 & 2 & 6.7 \\
\hline 15 & 3 & 10 & 11 & 36.7 & 9 & 30 & 4 & 13.3 & 3 & 10 \\
\hline 16 & 3 & 10 & 11 & 36.7 & 10 & 33.3 & 4 & 13.3 & 2 & 6.7 \\
\hline
\end{tabular}

The table indicated almost all of the instructors keep in mind the problem that they have with one of their colleagues and most of them prefer to suppress their feelings about that problem, and they dislike when a colleague wants to show off his/her abilities or when they says unpleasant stuff about them.

In this study, two questions devised for each of the next two categories which are related to the instructors' anger towards the institutional context and towards students that are presented in Table 4, and 5 respectively.

Table 4. Item frequency and percentages of anger towards the institutional context category

\begin{tabular}{|c|c|c|c|c|c|c|c|c|c|c|}
\hline & \multicolumn{10}{|c|}{ Instructors' Responses } \\
\hline & & & & & & & & & & \\
\hline \multirow[t]{2}{*}{ Items } & \multicolumn{2}{|c|}{ Strongly Agree } & \multicolumn{2}{|c|}{ Agree } & \multicolumn{2}{|c|}{$\begin{array}{c}\text { Somewhat Agree/ } \\
\text { Disagree }\end{array}$} & \multicolumn{2}{|c|}{ Disagree } & \multicolumn{2}{|c|}{ Strongly Disagree } \\
\hline & $\mathbf{F}$ & $\%$ & $\mathbf{F}$ & $\%$ & $\mathbf{F}$ & $\%$ & $\mathbf{F}$ & $\%$ & $\mathbf{F}$ & $\%$ \\
\hline 17 & 5 & 16.7 & 8 & 26.7 & 14 & 46.7 & 2 & 6.7 & 1 & 3.3 \\
\hline 18 & 1 & 3.3 & 2 & 6.7 & 6 & 20 & 12 & 40 & 9 & 30 \\
\hline
\end{tabular}

This table shows that when the instructors feel angry of the institutional context, they mostly try to be positive and deal with it but they refuse to talk to its manager. 
Table 5. Item frequency and percentages of anger towards students category

Instructors' Responses

\begin{tabular}{|c|c|c|c|c|c|c|c|c|c|c|}
\hline \multirow[t]{2}{*}{ Items } & \multicolumn{2}{|c|}{$\begin{array}{c}1 \\
\text { Strongly Agree }\end{array}$} & \multicolumn{2}{|c|}{$\begin{array}{c}2 \\
\text { Agree }\end{array}$} & \multicolumn{2}{|c|}{$\begin{array}{c}3 \\
\text { Somewhat Agree/ } \\
\text { Disagree }\end{array}$} & \multicolumn{2}{|c|}{$\begin{array}{c}4 \\
\text { Disagree }\end{array}$} & \multicolumn{2}{|c|}{$\begin{array}{c}5 \\
\text { Strongly Disagree }\end{array}$} \\
\hline & $\mathbf{F}$ & $\%$ & $\mathbf{F}$ & $\%$ & $\mathbf{F}$ & $\%$ & $\mathbf{F}$ & $\%$ & $\mathbf{F}$ & $\%$ \\
\hline 19 & 1 & 3.3 & 2 & 6.7 & 5 & 16.7 & 14 & 46.7 & 8 & 26.7 \\
\hline 20 & 6 & 20 & 13 & 43.3 & 10 & 33.3 & 1 & 3.3 & 0 & 0 \\
\hline
\end{tabular}

The results of this table are an evidence that the instructors are disagree with the statement that as they know their students haven't got a good sense of learning, they won't become angry with them. On the other hand, most of them are annoyed when they are aware their students keeps on committing the same mistakes.

Table 6. Item frequency and percentages of being close to students category

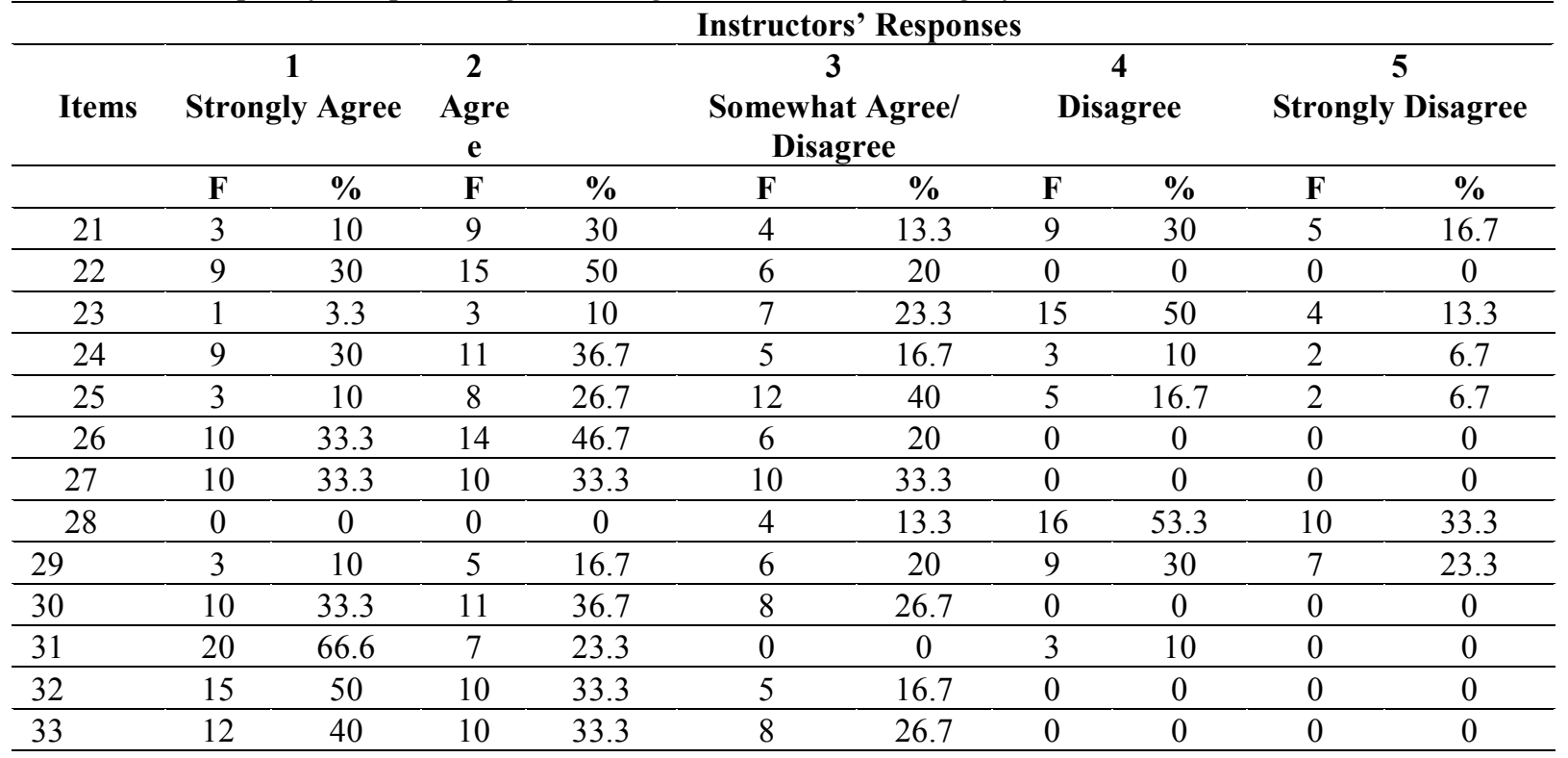

About the relations between the instructors and their students, the table shows that almost half of them expressed that they are close to their students when they are adults and the rest expressed close relationships when their students are not adults. In spite of this, all of them feel very close to their students when they share interests with them. They stated that in spite of friendly atmosphere in the class, most of their close friends are not among their students. Most of the instructors indicated that they as English instructors are closer to their students than other instructors and many borders among them and their students are eliminated. According to the answers, all of the instructors were agreed that they've gone beyond their roles as a university instructor and become a "moral guide" to their students by they all the time consider some redlines for this issue and they try to not be indifferent to the topics. They are all careful with the opposite sex especially at the beginning of the term that they don't know their points of strength, but they try to be equal to all students. At the end they claimed that cultural and social norms affect their treatment with their students.

In Table 7 below, the instructors' emotions and staffs is discussed. As it is clear in their answers, they usually don't talk with the staff about anything beyond the work and they somewhat are able to ask a colleague for assistance when it is necessary.

Table 7. Item frequency and percentages of emotions and staff category

\begin{tabular}{|c|c|c|c|c|c|c|c|c|c|c|}
\hline \multirow{3}{*}{ Items } & \multicolumn{10}{|c|}{ Instructors' Responses } \\
\hline & \multicolumn{2}{|c|}{$\begin{array}{c}1 \\
\text { Strongly Agree }\end{array}$} & \multicolumn{2}{|c|}{$\begin{array}{c}2 \\
\text { Agree }\end{array}$} & \multicolumn{2}{|c|}{$\begin{array}{c}3 \\
\text { Somewhat Agree/ } \\
\text { Disagree }\end{array}$} & \multicolumn{2}{|c|}{$\begin{array}{c}4 \\
\text { Disagree }\end{array}$} & \multicolumn{2}{|c|}{$\begin{array}{c}5 \\
\text { Strongly Disagree }\end{array}$} \\
\hline & $\mathbf{F}$ & $\%$ & $\mathbf{F}$ & $\%$ & $\mathbf{F}$ & $\%$ & $\mathbf{F}$ & $\%$ & $\mathbf{F}$ & $\%$ \\
\hline 34 & 10 & 33.3 & 11 & 36.7 & 9 & 30 & 0 & 0 & 0 & 0 \\
\hline 35 & 4 & 13.3 & 4 & 13.3 & 18 & 60 & 4 & 13.3 & 0 & 0 \\
\hline
\end{tabular}

Table 8 below makes some information of creating rapport. The answers to the first question of this category show that all of them prefer to use topics that their students can share and most of them highlight the positive features of their students or use some sense of humor. But the answers to the fourth and fifth questions of this category show that most 
of these instructors do not end class discussions with personal issues and in contrast, they respect all the ideas in their classes without any personal criticism.

Table 8 . Item frequency and percentages of creating rapport category

\begin{tabular}{|c|c|c|c|c|c|c|c|c|c|c|}
\hline \multirow{4}{*}{ Items } & \multicolumn{10}{|c|}{ Instructors' Responses } \\
\hline & \multirow{2}{*}{\multicolumn{2}{|c|}{$\begin{array}{c}1 \\
\text { Strongly Agree }\end{array}$}} & \multirow{2}{*}{\multicolumn{2}{|c|}{$\begin{array}{c}2 \\
\text { Agree }\end{array}$}} & \multirow{2}{*}{\multicolumn{2}{|c|}{$\begin{array}{c}3 \\
\begin{array}{c}\text { Somewhat Agree/ } \\
\text { Disagree }\end{array} \\
\end{array}$}} & \multirow{2}{*}{\multicolumn{2}{|c|}{$\begin{array}{c}4 \\
\text { Disagree }\end{array}$}} & \multirow{2}{*}{\multicolumn{2}{|c|}{$\begin{array}{c}5 \\
\text { Strongly Disagree }\end{array}$}} \\
\hline & & & & & & & & & & \\
\hline & $\mathbf{F}$ & $\%$ & $\mathbf{F}$ & $\%$ & $\mathbf{F}$ & $\%$ & $\mathbf{F}$ & $\%$ & $\mathbf{F}$ & $\%$ \\
\hline 36 & 11 & 36.7 & 10 & 33.3 & 9 & 30 & 0 & 0 & 0 & 0 \\
\hline 37 & 7 & 23.3 & 14 & 46.7 & 9 & 30 & 0 & 0 & 0 & 0 \\
\hline 38 & 12 & 40 & 7 & 23.3 & 11 & 36.7 & 0 & 0 & 0 & 0 \\
\hline 39 & 0 & 0 & 2 & 6.7 & 5 & 16.7 & 15 & 50 & 8 & 26.7 \\
\hline 40 & 13 & 43.3 & 14 & 46.7 & 3 & 10 & 0 & 0 & 0 & 0 \\
\hline
\end{tabular}

Table 9 summarizes the findings of seven questions of collaboration category. In this table, the instructors indicated that they have some meeting in order to collaborate with each other but these meetings are not regular. Most of them expressed that they don't share information via email by each other. They said that there is a respectful relationship between them and colleagues and sometimes some of them become close friends. Most of the instructors refused very formal relationship with the staffs and most of them to somewhat know the names of people working at the university but they are not close.

Table 9. Item frequency and percentages of collaboration category

\begin{tabular}{|c|c|c|c|c|c|c|c|c|c|c|}
\hline & \multicolumn{10}{|c|}{ Instructors' Responses } \\
\hline \multirow{3}{*}{ Items } & \multirow{2}{*}{\multicolumn{2}{|c|}{$\begin{array}{c}1 \\
\text { Strongly Agree }\end{array}$}} & \multirow{2}{*}{\multicolumn{2}{|c|}{$\begin{array}{c}2 \\
\text { Agree }\end{array}$}} & \multirow{2}{*}{\multicolumn{2}{|c|}{$\begin{array}{c}3 \\
\text { Somewhat Agree/ } \\
\text { Disagree }\end{array}$}} & \multirow{2}{*}{\multicolumn{2}{|c|}{$\begin{array}{c}4 \\
\text { Disagree }\end{array}$}} & \multirow{2}{*}{\multicolumn{2}{|c|}{$\begin{array}{c}5 \\
\text { Strongly Disagree }\end{array}$}} \\
\hline & & & & & & & & & & \\
\hline & $\mathbf{F}$ & $\%$ & $\mathbf{F}$ & $\%$ & $\mathbf{F}$ & $\%$ & $\mathbf{F}$ & $\%$ & $\mathbf{F}$ & $\%$ \\
\hline 41 & 0 & 0 & 0 & 0 & 3 & 10 & 17 & 56.6 & 10 & 33.3 \\
\hline 42 & 10 & 33.3 & 16 & 53.3 & 4 & 13.3 & 0 & 0 & 0 & 0 \\
\hline 43 & 1 & 3.3 & 4 & 13.3 & 5 & 16.7 & 10 & 33.3 & 10 & 33.3 \\
\hline 44 & 19 & 63.3 & 9 & 30 & 2 & 6.7 & 0 & 0 & 0 & 0 \\
\hline 45 & 20 & 66.6 & 5 & 16.7 & 5 & 16.7 & 0 & 0 & 0 & 0 \\
\hline 46 & 4 & 13.3 & 6 & 20 & 4 & 13.3 & 10 & 33.3 & 6 & 20 \\
\hline 47 & 5 & 16.7 & 7 & 23.3 & 12 & 40 & 3 & 10 & 3 & 10 \\
\hline
\end{tabular}

The last table is about general feelings of instructors towards their career that as the table shows, almost half of them think positive about their job and the rest do not. All of them stated that their job is one of the priorities in their life, but believed that long hours of work make them so tired. They mostly were not agree that teaching is the best thing they can do but about all of them enjoyed teaching because of interacting with students and as most of them liked dealing with other people, it is difficult for them to quit teaching profession because they believe that teaching is a social life. At last, most of them indicated that they would choose teaching one more time if they had to choose again.

Table 10. Item frequency and percentages of general feeling towards your career category

\begin{tabular}{|c|c|c|c|c|c|c|c|c|c|c|}
\hline \multirow{3}{*}{ Items } & \multicolumn{10}{|c|}{ Instructors' Responses } \\
\hline & \multicolumn{2}{|c|}{$\begin{array}{c}1 \\
\text { Strongly Agree }\end{array}$} & \multicolumn{2}{|c|}{$\begin{array}{c}2 \\
\text { Agree }\end{array}$} & \multicolumn{2}{|c|}{$\begin{array}{c}3 \\
\text { Somewhat Agree/ } \\
\text { Disagree }\end{array}$} & \multicolumn{2}{|c|}{$\begin{array}{c}4 \\
\text { Disagree }\end{array}$} & \multicolumn{2}{|c|}{$\begin{array}{c}5 \\
\text { Strongly Disagree }\end{array}$} \\
\hline & $\mathbf{F}$ & $\%$ & $\mathbf{F}$ & $\%$ & $\mathbf{F}$ & $\%$ & $\mathbf{F}$ & $\%$ & $\mathbf{F}$ & $\%$ \\
\hline 48 & 4 & 13.3 & 6 & 20 & 11 & 36.7 & 4 & 13.3 & 5 & 16.7 \\
\hline 49 & 23 & 76.6 & 5 & 16.7 & 2 & 6.7 & 0 & 0 & 0 & 0 \\
\hline 50 & 4 & 13.3 & 4 & 13.3 & 15 & 50 & 5 & 16.7 & 2 & 6.7 \\
\hline 51 & 4 & 13.3 & 6 & 20 & 6 & 20 & 9 & 30 & 5 & 16.7 \\
\hline 52 & 7 & 23.3 & 6 & 20 & 15 & 50 & 2 & 6.7 & 0 & 0 \\
\hline 53 & 11 & 36.7 & 4 & 13.3 & 10 & 33.3 & 4 & 13.3 & 1 & 3.3 \\
\hline 54 & 5 & 16.7 & 9 & 30 & 8 & 26.7 & 5 & 16.7 & 3 & 10 \\
\hline 55 & 11 & 36.7 & 9 & 30 & 6 & 20 & 3 & 10 & 1 & 3.3 \\
\hline 56 & 9 & 30 & 8 & 26.7 & 5 & 16.7 & 5 & 16.7 & 3 & 10 \\
\hline
\end{tabular}




\section{Discussion}

Study results indicated different emotional attitudes of the instructors. Results showed that most of the instructors were satisfied from interacting with the students mainly when they are appreciated as a good teacher by them. The financial aspect of teaching is important for some of them but all of them enjoy their students' improvement. The data showed that the dissatisfactions of the instructors were mainly related to their observation or the inability of their students in cooperating or doing their best. The data related to the colleagues category show that there are no strong relationships between them. The answers showed that the instructors may some problems with the institutional context but most of the time they suppress their anger towards it. The instructors are annoyed when they feel their students haven't got a good sense of learning or they are repeating the same problem for several times. The findings about age and sex of the students were not significant but most of the instructors indicated that they enjoy sharing interests with their students and they, as English instructors are closer to their students rather than the other instructors. They act as a "moral guide" to their students but they consider redlines for this issue all the time. All of the instructors preferred to use topics that their students could share. Their relationship with their colleagues was a respectful one and just some of them tried to be close friend with each other. Generally speaking, their attitude towards their carrier was positive, although social and cultural issues were effective in their treatments too.

\section{Conclusion}

This study investigated the effect of emotional attitudes of TEFL university instructors towards their students, colleagues and workplace. It came to light that the events occur in the classroom aren't affectless on instructors. For example, the progress in learning of the students and also their satisfaction from their teachers' teaching style are the cases which cause some satisfaction emotional attitudes in the instructors; on the other hand, inability of the learners in doing their best is among the cases that make the instructors dissatisfied.

In light of the findings, it calls the educational organizations to allocate special values for emotional attitudes of their instructors and to arrange some meetings to ask their problems and to prepare them with required facilities in order to reach to better results in teaching.

However, a number of caveats need to be noted regarding the current study. First, this study lacked a vast number of participants; further, the sample included in the study was not selected randomly; therefore, the generalizability of the results should be done with caution.

Finally, some fertile avenues for further research are worth mentioning. Due to dearth of empirical studies on the potential of teachers' emotional attitudes towards their students, colleagues, and workplace for fostering different dimensions and components of language learning processes, further research are required to explore this issue. In this study, a modal kind of questionnaire was used, rather it is suggested that the further studies can try some different kinds of questionnaire or even try to design more effective questionnaires to meet this end. Additionally, examining the effects of emotional attitudes for the participants with just one kind of degree and examining different variables such as their gender, age, years of experience... are interesting points for further investigation.

\section{References}

Cowie, N. (2003, November). The emotional lives of experienced EFL teachers. In Proceedings of JALT 2003 Conference, Shizuoka, Japan (pp. 256-259).

Cowie, N. (2010). Emotions that experienced EFL teachers feel about their students, their colleagues and their work. Teaching and Teacher Education, 235-241.

Ghanizadeh, A., \& Moafian, F. (2010). The role of EFL teachers' emotional intelligence in their success. ELT journal, 64(4), 424-435.

Hargreaves, A. (1998). The emotional practice of teaching. Teaching and Teacher Education, 16, 811-826.

Hochschild, A. R. (1983). The managed heart: The commercialization of human feeling. (p. 7). Berkeley: University of California Press.

Hochschild, A. R. (1990). Ideology and emotion management: A perspective and path for future research.

Karami \& Barekat (2014). Opertionalizing teachers' emotional attitudes towards their students, colleagues and workplace result from an EFL context. Journal of Language and Literature, 5(1),96-104.

Koçoğlu, Z. (2011). Emotional intelligence and teacher efficacy: a study of Turkish EFL pre-service teachers. Teacher Development, 15(4), 471-484.

Koestler, A. (1967). The ghost in the machine. (p. 226), London: Hutchinson.

Nikoopour, J., Farsani, M. A., Tajbakhsh, M., \& Kiyaie, S. H. S. (2012). The Relationship between Trait Emotional Intelligence and Self-efficacy among Iranian EFL Teachers. Journal of Language Teaching and Research, 3(6), 11651174.

Petrides, K. V., \& Furnham, A. (2006). The Role of Trait Emotional Intelligence in a Gender- Specific Model of Organizational Variables1. Journal of Applied Social Psychology, 36(2), 552-569. 
Prosen, S., Smrtnik Vitulic, H., \& Poljsak Skraban, O. (2011). Teachers' emotional expression in interaction with students of different ages. CEPS Journal, 1(3), 141-157.

Rastegar, M., \& Memarpour, S. (2009). The relationship between emotional intelligence and self- efficacy among Iranian EFL teachers. System, 37(4), 700-707.

Rose, N. (1998). Inventing ourselves: Psychology, power, and personhood. Cambridge University Press.

Schutte, N. S., Malouff, J. M., Hall, L. E., Haggerty, D. J., Cooper, J. T., Golden, C. J., et al. (1998). Development and validation of a measure of emotional intelligence. Personality and Individual Differences , 25, 167-177.

Smith, R. C. (1996). Contents and Activities in Team Teaching: Lessons From Observation. In M. Wada, \& A. Cominos, Studies in Team Teaching (pp. 72-89). Tokyo: Kenkyusha Publishing Co.

Staub, F. C., \& Stern, E. (2002). The nature of teachers' pedagogical content beliefs matters for students' achievement gains: Quasi-experimental evidence from elementary mathematics. Journal of Educational Psychology, 94(2), 344.

Tschannen-Moran, M., \& Hoy, A. W. (2001). Teacher efficacy: Capturing an elusive construct. Teaching and teacher education, 17(7), 783-805.

Zembylas, M. (2005). Teaching with emotion: a postmodern enactment. Greenwich: Information Age Publishing.

\section{APPENDIX: Questionnaire}

\section{General information}

\section{All information is completely confidential.}

Age: ....

Gender: male / female

Years of language teaching experience: ...

Field of study/Degree: ....

$>$ Instruction: You are kindly requested to fill this questionnaire, which has been especially designed for our research on Teachers' Emotional Attitudes towards their Students, Colleagues and Workplace. We appreciate your sincere responses, which are no doubt of great value to our purpose. Please read the following questions and choose one answer from strongly agree(1) to strongly disagree(5).

\begin{tabular}{|c|c|c|c|c|c|c|}
\hline & & $\begin{array}{c}\text { Strongly } \\
\text { Agree } \\
\text { (1) } \\
\end{array}$ & $\begin{array}{l}\text { Agree } \\
\text { (2) } \\
\end{array}$ & $\begin{array}{c}\text { Somewhat } \\
\text { agree/disagree } \\
\text { (3) } \\
\end{array}$ & $\begin{array}{c}\text { Disagree } \\
(4) \\
\end{array}$ & $\begin{array}{c}\text { Strongly } \\
\text { Disagree } \\
(5) \\
\end{array}$ \\
\hline \multicolumn{7}{|c|}{$>$ Satisfaction } \\
\hline 1. & $\begin{array}{l}\text { I feel satisfied whenever I hear others appreciating me as a good teacher and } \\
\text { compliment my effort to teach. }\end{array}$ & & & & & \\
\hline 2. & The most important source of my satisfaction is my income (financial aspects). & & & & & \\
\hline 3. & My students are the reasons that I feel satisfied with my job. & & & & & \\
\hline 4. & I love my job. & & & & & \\
\hline 5. & I feel satisfied with my job because of the interaction between me and my students. & & & & & \\
\hline 6. & I feel satisfied whenever I see my students' improvement. & & & & & \\
\hline & \multicolumn{6}{|l|}{$>\quad$ Dissatisfaction } \\
\hline 7. & I feel dissatisfied whenever I cannot do my best. & & & & & \\
\hline 8. & I feel dissatisfied when students are not cooperating. & & & & & \\
\hline 9. & I feel dissatisfied when I am constantly checked through observations, cameras, etc. & & & & & \\
\hline 10. & I feel dissatisfied with my job because I have to censor myself and I am not free. & & & & & \\
\hline 11. & Heterogeneous classes make me feel dissatisfied. & & & & & \\
\hline 12. & $\begin{array}{l}\text { I feel dissatisfied because students have traditional beliefs towards learning and they } \\
\text { don't accept new methods. }\end{array}$ & & & & & \\
\hline & \multicolumn{6}{|l|}{$>\quad$ Interaction with Colleagues } \\
\hline 13. & When I have a problem with a colleague, I'd rather keep it in my mind. & & & & & \\
\hline 14. & When I have a problem with a colleague, I just suppress my feeling. & & & & & \\
\hline 15. & I feel mad at my colleagues, when they just want to show off their abilities. & & & & & \\
\hline 16. & I feel mad at my colleagues, when they say unpleasant stuff about me. & & & & & \\
\hline & \multicolumn{6}{|l|}{$>\quad$ Anger towards the Institutional Context } \\
\hline & $\begin{array}{l}\text { Whenever I feel angry because of the institutional context, I try to be positive and deal } \\
\text { with it. }\end{array}$ & & & & & \\
\hline & $\begin{array}{l}\text { Whenever I feel angry because of the institutional context, I would talk with the } \\
\text { manager. }\end{array}$ & & & & & \\
\hline
\end{tabular}




\section{$>$ Anger towards Students}

19. I wouldn't become angry with the students because I know they haven't got a good sense of learning.

20. I am annoyed when a student keeps on committing the same mistakes.

\section{$>$ Being Close to Students}

21. When my students are adults, I am very close to them.

22. When my students share interests with me, I feel very close to them.

23. Most of my close friends are my students.

24. There is a friendly atmosphere in the class but my students are not my friends.

25. As an English teacher, I am closer to my students than other teachers and I try to eliminate the boarders between teacher and students.

26. I've gone beyond my role as teacher and become a "moral guide" to my students, because I believe that we are teaching the culture as well.

27. Sometimes I go beyond my role, but I think we have got to have some redlines.

28. I don't go beyond my role and I try to be indifferent to the topics.

29. I think you've got to be more careful with the opposite sex.

30. I think you've got to be more careful at the beginning of the term when you don't know their points of strength.

31. I try to be equal to all my students, no matter they are male or female.

32. Sometimes because of cultural reasons you may unintentionally make a difference.

33. You have to follow the social norms, because of that I DO treat my students differently.

\section{Emotions and Staff}

34. I usually don't talk with the staff about anything beyond the work.

35. When it is necessary, I am able to ask a colleague for assistance.

\section{$>$ Creating Rapport}

36. In order to create rapport with my students, I go for topics that they can share.

37. In order to create rapport, you highlight their positive features.

38. In order to create rapport, having some sense of humor would help.

39. In order to create rapport, I usually start with their interests and then we progress to more personal issues.

40. In order to create rapport, I respect all the ideas in my class without any personal criticism

\section{$>$ Collaboration}

41. In order to collaborate with other colleagues, we have regular meetings at the university.

42. In order to collaborate with other colleagues, we have meetings but they are not regular.

43. Sometimes we share any piece of useful information through email with each other.

44. There is a respectful relationship between me and my colleagues.

45. Some of my colleagues have become my close friends.

46. My relation with the staff is just a formal one.

47. I know the names of people working at the institute, but we are not close.

\section{$>$ General Feeling towards Your Career}

48. I generally feel so positive about my job.

49. My job is one of the priorities in my life.

50. I like my job but the long hours of work make me feel so tired.

51. Teaching is the best thing I can do.

52. I like my job because of the interaction with the students.

53. Teaching is indeed a fulfilling job.

54. I can never quit teaching cause I like dealing with people.

55. Teaching is not a boring job, it is rather a social life.

56. I feel that if I had to choose again, I would choose teaching one more time

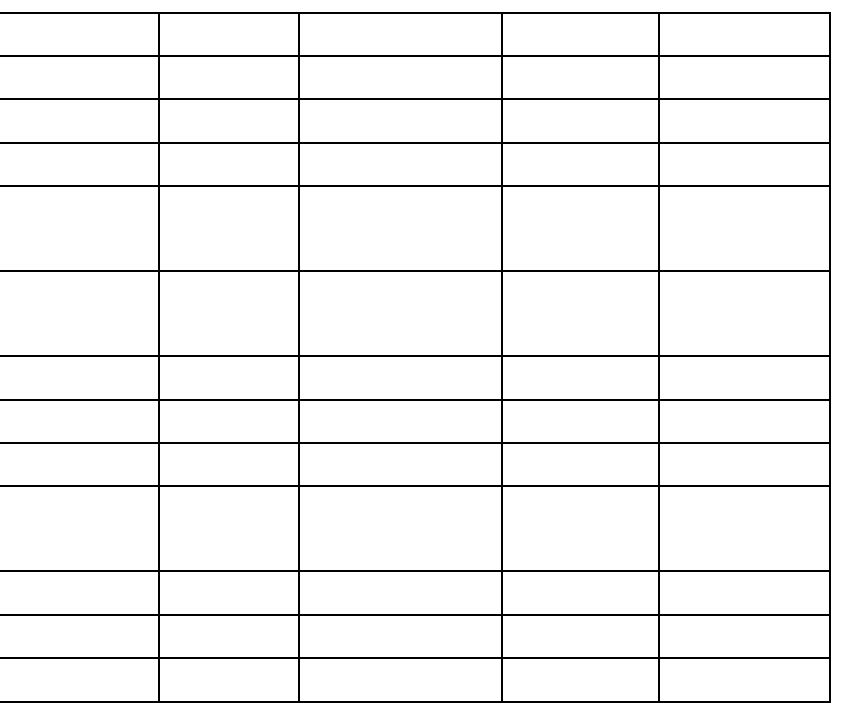

